\title{
Bartosz Edwarczyk Możliwość zwiększania dochodów osiąganych z majątku komunalnego
}

Possibility of increasing revenues from municipal assets

The article examines municipal assets' management in the context of the revenue derived from assets by municipalities and cities with powiat status in Poland. The author first describes the specificity of the financial management in the public sector, with particular emphasis on the revenues obtained by local government units from assets. Next, based on the study of a sample of Polish municipalities and cities with powiat status, he describes changes to the revenue from municipal assets. In the final section, the possibilities of increasing revenue from this source are evaluated.

\begin{tabular}{r|l}
\hline DOI & https://doi.org/10.31268/StudiaBAS.2021.12 \\
\hline Słowa kluczowe & $\begin{array}{l}\text { gospodarowanie majątkiem, dochody z majątku komunalnego, } \\
\text { dochody ze sprzedaży, zarządzanie finansami publicznymi, samorząd } \\
\text { terytorialny w Polsce }\end{array}$ \\
\hline Keywords & $\begin{array}{l}\text { asset management, revenue from municipal assets, revenue from } \\
\text { sales, public financial management, local government in Poland }\end{array}$ \\
\hline O autorze & $\begin{array}{l}\text { doktor nauk społecznych w specjalności finanse publiczne, naczelnik } \\
\text { Pionu Audytu i Kontroli Urzędu Miejskiego w Śremie } ・ \\
凶 \text { bartosz.edwarczyk@wplpl P ORCID 0000-0003-2147-8153 }\end{array}$ \\
\hline
\end{tabular}

\section{Wstęp}

Narastające potrzeby i oczekiwania społeczeństwa w zakresie publicznie świadczonych usług i dostarczanych dóbr wpływają na racjonalne gospodarowanie ograniczonymi zasobami rzeczowymi i finansowymi. Efektywność gospodarowania zasobami w sektorze publicznym jest ważna ze względu na skalę oddziaływania, źródła jego finansowania utożsamiane z ciężarem społecznym, np. podatkami i opłatami, oraz kwalifikowanie zasobów materialnych jako dóbr publicznych, np. sieci kanalizacji, dróg ${ }^{1}$. Rozwój społeczny, gospodarczy i przestrzenny wiąże się z polepszeniem warunków jakości życia mieszkańców wspólnot lokalnych. Zmiany te jednak również niosą ze sobą zwiększanie potrzeb w zakresie dostępności do majątku publicznego, w szczególności infrastruktury użyteczności publicznej. W sytuacji ograniczonych zasobów (finansowych i rzeczowych) ważne jest utrzymanie równowagi między realizowaną gospodarką finansową a majątkiem zarządzanym przez jednostki samorządu terytorialnego. Niewłaściwe postępowanie prowadzące do destabilizacji polityki majątkowo-finansowej samorządu terytorialnego skutkuje zwiększaniem się deficytu (luki) majątku komunalnego w stosunku do potrzeb.

Celem opracowania jest określenie możliwości zwiększania wpływów z majątku komunalnego w aktualnym stanie prawnym. W zamiarze osiągnięcia przyjętego celu zbadano dochody z majątku osiągnięte przez gminy i miasta na prawach powiatu w Polsce w latach 2007-2019.

B. Edwarczyk, Rola wpływów z gospodarowania majątkiem w wypełnianiu reguł zadłużenia przez jednostki samorzqdu terytorialnego, "Studia BAS" 2016, nr 3(47) [Nowe tendencje w zarzq̨dzaniu finansami publicznymi, red. M. Korolewska, Z. Szpringer], s. 174. 
Ocenie poddano wielkość i strukturę źródeł uzyskanych dochodów z majątku komunalnego w porównaniu z wydatkami majątkowymi. Punktem wyjścia do rozważań na łamach opracowania, stanowiącym uzupełnienie tematu, jest prezentacja istoty i roli zarządzania majątkiem komunalnym w systemie finansów publicznych w Polsce, w szczególności w zakresie realizacji dochodów wskutek tego zarządzania.

\section{Zarządzanie majątkiem komunalnym w systemie finansów publicznych}

Działalność władz w sektorze publicznym wiąże się z realizacją zadań publicznych prowadzonych z wykorzystaniem dwóch obszarów: rzeczowego i finansowego. Na obszar rzeczowy sektora publicznego składa się majątek publiczny, stanowiący dobra publiczne albo pozwalający na tworzenie tych dóbr. Ujęcie rzeczowe obejmuje realne zjawiska i procesy gospodarcze. Obszar ten dotyczy majątku publicznego (mienia), takiego jak: lasy, zasoby wody, drogi, sieci kanalizacji i budynki użyteczności publicznej². Jednostka samorządu terytorialnego (JST) sprawująca władzę publiczną jest szczególnym podmiotem gospodarowania, co wynika z posiadania samodzielności decyzyjnej, a także dysponowania własną administracją, majątkiem i finansami ${ }^{3}$. Podstawowym celem wyposażenia w majątek JST było zabezpieczenie ich samodzielności w ujęciu cywilnoprawnym ${ }^{4}$. W ocenie S. Owsiaka majątek komunalny powinien stanowić istotne źródło zasilania finansowego wspólnoty lokalnej ${ }^{5}$.

Na początek warto zauważyć, że w sektorze publicznym pojęcie „majątek” jest przyrównywane do pojęcia „mienie”. Wskutek nowelizacji ${ }^{6}$ Kodeksu cywilnego ${ }^{7}$ w 1990 r. podstawą klasyfikacji mienia w ujęciu cywilistycznym zostało kryterium przedmiotowe ${ }^{8}$. Obecnie mienie oznacza ogół praw majątkowych: „Mieniem jest własność i inne prawa majątkowe” (art. 44 k.c.). W skład praw majątkowych przede wszystkim wchodzą takie prawa rzeczowe, jak: własność, użytkowanie wieczyste i ograniczone prawa rzeczowe (służebność, użytkowanie, zastaw, spółdzielcze własnościowe prawo do lokalu oraz hipoteka), jak również inne prawa, np. wierzytelności, prawa wynikające ze stosunków zobowiązań (najem, dzierżawa), prawa na dobrach niematerialnych o charakterze majątkowym (prawo własności intelektualnej) i prawo spadkowe

2 W. Ziółkowska, Finanse publiczne. Teoria i zastosowanie, Wydawnictwo Wyższej Szkoły Bankowej w Poznaniu, Poznań 2010, s. 14-15; por. S. Owsiak, Finanse publiczne. Współczesne ujęcie, Wydawnictwo Naukowe PWN, Warszawa 2017, s. 137.

3 E. Wojciechowski, Zarządzanie w samorzq̨dzie terytorialnym, wyd. 2 poprawione i rozszerzone, Difin, Warszawa 2012, s. 29.

4 H. Izdebski, Samorząd terytorialny. Podstawy ustroju i działalności, wyd. 1, LexisNexis, Warszawa 2009, s. 274.

5 S. Owsiak, Finanse publiczne. Teoria i praktyka, Wydawnictwo Naukowe PWN, Warszawa 2005, s. 142.

6 Na mocy ustawy z dnia 28 lipca 1990 r. o zmianie ustawy - Kodeks cywilny (Dz.U. nr 55, poz. 321).

7 Ustawa z dnia 23 kwietnia 1964 r. - Kodeks cywilny (Dz.U. 2020, poz. 1740, ze zm.); dalej: k.c.

8 J. Winiarz et al., Kodeks cywilny z komentarzem, red. J. Winiarz, wyd. 2 zmienione, t. 1, Wydawnictwo Prawnicze, Warszawa 1989, s. 58.

9 M. Bednarek, Mienie. Komentarz do art. 44-55 Kodeksu cywilnego, Kantor Wydawniczy Zakamycze, Kraków 1997, s. 21-23. 
Pojęcie „mienie” często też jest utożsamiane z - a nawet zastępowane - pojęciem "majątek"10. W jeszcze węższym znaczeniu pojęcie to jest rozumiane jako zasób nieruchomości JST ${ }^{11}$. Praktyka rozróżnienia i stosowania pojęć „mienie” i „majątek" wynika z niekonsekwencji ich użycia w polskiej legislacji, np. w ustawie z dnia 27 sierpnia 2009 r. o finansach publicznych $^{12}$ ustawodawca wyróżnia „dochody z mienia” (art. 5 ust. 2 pkt 4) oraz odrębną kategorię: „dochody ze sprzedaży majątku, rzeczy i praw” (art. 5 ust. 2 pkt 8). Podstawowa różnica w odniesieniu do zakresu i charakteru pojęć „mienie” $\mathrm{i}$ „majątek" wiąże się ze sposobem strukturyzacji praw majątkowych (mienie to prosta suma praw, majątek zaś poza sumą praw majątkowych obejmuje także ich funkcjonalną konfigurację). Ponadto pojęcie „mienie” odnosi się jedynie do zbioru praw majątkowych (aktywów). Obowiązki (długi, zobowiązania, kapitał) nie składają się na mienie, ponieważ obciążają własność i inne prawa majątkowe. Pojęcie „majątek" jest używane na dwa sposoby. W szerszym znaczeniu przez „majątek” rozumie się zbiór praw i obowiązków majątkowych (zbiór aktywów i pasywów), z kolei w węższym ujęciu „majątek" obejmuje tylko prawa (aktywa). Węższe podejście pozwala na utożsamianie majątku z mieniem ze względu na zakres podmiotowych praw majątkowych, skutki prawne i wartość majątkową. Pojęcie "majątek" jest zrelatywizowane do zbioru aktywów zindywidualizowanej osoby fizycznej lub osoby prawnej, podczas gdy pojęcie „mienie” dotyczy zbioru aktywów określonego typu osób prawnych, np. mienie państwowe, mienie komunalne ${ }^{13}$. Wyodrębnienie pojęcia „majątek" pozwala na posługiwanie się nim, co jest przydatne, gdy mówimy np. o zarządzaniu majątkiem, w tym o pobieraniu pożytku z majątku, czy o odpowiedzialności majątkiem za długi ${ }^{14}$. W tym miejscu należy zaznaczyć, że autor artykułu przyjmuje węższą interpretację pojęcia "majątek", zgodnie z którą majątek JST jest utożsamiany z mieniem (aktywami w ujęciu syntetycznym $)^{15}$.

Po ustaleniu zakresu przedmiotowego pojęcia „majątek” niezbędne jest odniesienie się do podmiotu badania, określonego słowem „komunalny". W klasycznym ujęciu „komuna” jest wyrazem przejętym z łaciny, oznaczającym „gmina”, a więc analogicznie - „komunalny" wiąże się z wyrazem "gminny". Gospodarkę komunalną czy przedsiębiorstwo komunalne dawniej określano mianem działalności gospodarczej gminy lub przedsiębiorstwa należącego do gminy. Obecnie gospodarka komunalna jest zdefiniowana przedmiotowo i obejmuje obsługę ludności w takich dziedzinach, jak dostawa wody, odprowadzanie ścieków i wywóz odpadów ${ }^{16}$. Przymiotnik „komunalny" przypisany mieniu już był używany przed 1990 r., jednak dopiero na skutek wyodrębnienia samorządu gminnego i jego wyposażenia w majątek pojęcie to zostało

10 B. Filipiak, Finanse samorzqdowe. Nowe wyzwania bieżące i perspektywiczne, Difin, Warszawa 2011, s. 185.

11 J. Kotlińska, Finansowe aspekty gospodarki nieruchomościami komunalnymi w Polsce (na przykładzie dużych miast), Wydawnictwo Uniwersytetu Ekonomicznego w Poznaniu, Poznań 2009, s. 43.

12 Dz.U. 2021, poz. 305; dalej: u.f.p.

13 M. Bednarek, op. cit., s. 30.

14 K. Osajda, Kodeks cywilny. Komentarz, wyd. 15, C.H. Beck, Warszawa 2015, s. 8, Legalis.

15 Wyrok Sądu Apelacyjnego w Łodzi - I Wydział Cywilny z 28 marca 2014 r., I ACa 1278/13, LEX nr 1451723.

16 J. Regulski, Samorząd III Rzeczypospolitej. Koncepcje i realizacja, Wydawnictwo Naukowe PWN, Warszawa 2000, s. 213. 
przyporządkowane samorządom terytorialnym (gminom do 1998 r.) ${ }^{17}$. Wraz z wdrożeniem reformy ustrojowej w 1999 r. wyraz "komunalny" zastąpiono wyrazem "gminny". W szerszym znaczeniu pojęcie „komunalny” oznacza "samorządowy”, a więc zbiorczą nazwę dla wszystkich $\mathrm{JST}^{18}$. Na potrzeby artykułu autor przyjął jako podmiot badania gminy (wiejskie, miejskie i miejsko-wiejskie) oraz miasta na prawach powiatu (dalej: miasta) stanowiące szczególny rodzaj jednostki samorządu terytorialnego. Takie podejście wiąże się z pojęciem „komunalny” odnoszącym się do gminy jako podmiotu.

Majątek komunalny, w prostym ujęciu, składa się z zasobów: rzeczowych, niematerialnych i finansowych, w jakie zostały wyposażone lub jakie nabyły w ramach bieżącej działalności gminy i miasta. Zarządzanie majątkiem komunalnym to złożony proces, który nabiera specjalnego charakteru ze względu na to, że majątek ten należy do ogółu społeczności lokalnej i jest wykorzystywany do zaspokajania zbiorowych potrzeb użyteczności publicznej ${ }^{19}$. Majątek i finansowe środki publiczne należące do danej wspólnoty mieszkańców nadają publiczny status działalności JST. Zarządzanie majątkiem komunalnym wymaga holistycznego podejścia, ponieważ koncentracja uwagi wyłącznie na wybranych jego składnikach powoduje postępujący proces degradacji w zakresie pozostałych składników, od których zostało odwrócone zainteresowanie ${ }^{20}$. Zarządzanie majątkiem publicznym polega zatem na wykorzystywaniu tego majątku zgodnie z jego przeznaczeniem do realizacji celów i zadań publicznych w granicach ustanowionych praw i obowiązków dla władzy publicznej. Aby prawidłowo zarządzać majątkiem komunalnym, organy władzy odpowiedzialne za zarządzanie najczęściej posługują się instrukcjami określającymi zasady ewidencji, gospodarowania i inwentaryzacji majątku, obejmują majątek ubezpieczeniem od następstw nieszczęśliwych zdarzeń i podejmowanych decyzji, wykorzystują fizyczne i techniczne środki ochrony (system monitoringu) oraz powierzają bieżące utrzymanie innym podmiotom (outsourcing).

W polskim systemie finansów publicznych reguły zarządzania majątkiem opierają się na priorytetach i polityce finansowej władz publicznych. Reguły te, przede wszystkim o charakterze jakościowym, są określone w różnorodnych branżowych przepisach prawa. Władze samorządowe na mocy tych przepisów są umocowane do wprowadzania aktów prawa miejscowego oraz własnych, wewnętrznych uchwał i zarządzeń w zakresie sposobu oraz trybu podejmowania decyzji dotyczących spraw majątkowych. Jako przykład tego rodzaju regulacji można wymienić chociażby ustawę z dnia 21 sierpnia 1997 r. o gospodarce nieruchomościami ${ }^{21}$, która określa zadania dla organu wykonawczego gospodarującego posiadanym zasobem nieruchomości, np. ewidencjonowanie nieruchomości zgodnie z katastrem nieruchomości, sporządzanie planów realizacji polityki gospodarowania nieruchomościami zasobu, zabezpieczanie nieruchomości

17 Ustawa z dnia 8 marca 1990 r. o samorządzie terytorialnym (Dz.U. nr 16, poz. 95, ze zm.); obecnie: ustawa z dnia 8 marca 1990 r. o samorządzie gminnym (Dz.U. 2020, poz. 713, ze zm.).

18 B. Dolnicki, Samorząd terytorialny, wyd. 5, Wolters Kluwer, Warszawa 2012, s. 347; por. Z. Leoński, Samorząd terytorialny w RP, wyd. 5, C.H. Beck, Warszawa 2006, s. 75-76.

19 Ekonomika i zarzqdzanie miastem, red. R. Brol, Wydawnictwo Akademii Ekonomicznej im. Oskara Langego we Wrocławiu, Wrocław 2004, s. 68.

20 E. Wojciechowski, op. cit., s. 186.

21 Dz.U. 2020, poz. 1990, ze zm. 
przed uszkodzeniem lub zniszczeniem (art. 23 ust. 1). Innym przykładem jest ustawa z dnia 20 grudnia 1996 r. o gospodarce komunalnej ${ }^{22}$, w której wyszczególniono prawno-organizacyjne formy prowadzenia gospodarki komunalnej (zakład budżetowy, spółka prawa handlowego) art. 2, a także postanowiono, że JST mogą powierzać wykonywanie zadań, na podstawie umowy, osobom fizycznym, osobom prawnym lub jednostkom organizacyjnym nieposiadającym osobowości prawnej, z uwzględnieniem przepisów prawa - art. 3 ust. 1.

W sferze działalności JST praktyczne aspekty zarządzania majątkiem zazwyczaj nie znajdują takiego uznania, jak zarządzanie finansami. Nieodpowiednie zarządzanie majątkiem często wynika z niejasnych i rozproszonych reguł prawnych. Dyspersja reguł zarządzania majątkiem w wielu przepisach prawa utrudnia kontrolę zarządzania z uwzględnieniem kryteriów legalności, rzetelności i gospodarności. Ponadto nie ułatwia podejmowania decyzji przez władze samorządowe, zwiększa ryzyko działalności jednostki i przyczynia się do kreowania wrażenia niejasności i nieczytelności uregulowań oraz nadmiernej biurokracji. Umiejętność zarządzania majątkiem komunalnym wpływa na osiąganie celów JST wskutek odpowiedniego doboru struktury i pełnego wykorzystania użyteczności majątku²3.

Wyodrębnienie procesów zarządzania finansami w samorządzie terytorialnym oddziałuje na zadania i czynności realizowane przez osoby odpowiedzialne za prowadzenie gospodarki finansowej, w tym w zakresie gospodarowania majątkiem. Wysoka ranga zarządzania finansami w JST wiąże się z ważną rolą finansów publicznych w realizacji zadań publicznych. Dodatkowo, stan finansów jest uznawany za syntetyczną miarę sytuacji finansowej i potencjału rozwoju społeczno-gospodarczego ${ }^{24}$. Proces świadczenia usług i dostarczania dóbr publicznych zależy od dostępnej struktury składników majątku komunalnego, która przesądza o ilości i jakości oferowanych usług oraz dóbr publicznych ${ }^{25}$. Zarządzanie majątkiem powinno być ważnym źródłem dochodów własnych JST, pozwalającym na finansowanie zadań publicznych ${ }^{26}$.

\section{Dochody z majątku komunalnego - wyniki badań}

Zarządzanie majątkiem komunalnym jako proces jest w znacznej części sprzężony zwrotnie z zarządzaniem finansami przez JST. Związek majątkowo-finansowy jest ważny w kontekście źródeł finansowania majątku, w tym realizacji zadań publicznych w wyniku inwestycji. Jako przykłady należy wymienić: dochody ze sprzedaży majątku, dochody z najmu i dzierżawy, wydatki na budowę nowej albo modernizację i remont istniejącej infrastruktury, utrzymanie porządku i czystości obiektów użyteczności publicznej, dróg publicznych, parków. Struktura (wielkość, ro-

22 Dz.U. 2021, poz. 679.

23 M. Dylewski, Planowanie budżetowe w podsektorze samorzqdowym. Uwarunkowania, procedury, modele, Difin, Warszawa 2007, s. 72 i 75.

24 E. Wojciechowski, op. cit., s. 234-235.

25 A. Szewczuk, M. Zioło, Zarys ekonomiki sektora publicznego, Wydawnictwo Naukowe Uniwersytetu Szczecińskiego, Szczecin 2008, s. 53.

26 S. Czarnow, Działalność gospodarcza jednostek samorzq̨u terytorialnego, „Samorząd Terytorialny” 2007, nr 10, s. 22. 
dzaj) i użyteczność majątku (stan techniczny, funkcje użytkowe, zaawansowanie technologiczne) częściowo kształtują krótko- i długoterminową politykę finansową, a jednocześnie pozostają w zależności od polityki finansowej oraz otoczenia społeczno-gospodarczego ${ }^{27}$.

Wyposażenie JST we własny budżet i majątek na potrzeby realizacji powierzonych zadań publicznych określa ich samodzielność i niezależność od państwa. Przeniesienie części kompetencji, obowiązków i decyzji o alokacji środków pieniężnych na szczebel lokalny jest przejawem decentralizacji finansów publicznych.

Brak trwałych dochodów wpływa na ułomność decyzji i mało skuteczne działania władz samorządowych ${ }^{28}$. Według P. Swianiewicza źródła finansowania działalności JST można podzielić na następujące cztery grupy (niektórzy autorzy wyszczególniają trzy grupy):

- dochody własne;

- transfery z budżetu państwa, od innych samorządów lub z innych (pozabudżetowych) źródeł, będące subwencjami i dotacjami;

- udziały samorządów pochodzące z dzielenia wpływów z niektórych podatków pomiędzy szczeble władzy samorządowej i budżet państwa;

- środki zwrotne pochodzące z kredytów, pożyczek i emisji obligacji komunalnych ${ }^{29}$.

Do dochodów JST zalicza się dochody własne, subwencję ogólną i dotacje celowe z budżetu państwa, a także środki pochodzące ze źródeł zagranicznych niepodlegające zwrotowi, z budżetu Unii Europejskiej i inne środki określone w odrębnych ustawach (art. 3 ust. 1 i 3 ustawy z dnia 13 listopada 2003 r. o dochodach jednostek samorządu terytorialnego ${ }^{30}$; art. 167 ust. 2 Konstytucji RP ${ }^{31}$ ). Należy podkreślić, że w polskiej legislacji brak jest legalnej definicji pojęcia dochodów własnych JST, toteż pojawiające się definicje są wynikiem prób jego określenia w ujęciu teoretycznym. W ustawie o dochodach JST jedynie wyliczono źródła dochodów własnych dla jednostek. W zakresie takich samych źródeł wpływów dla wszystkich JST można wskazać takie dochody, jak: z majątku, ze spadków, zapisów i darowizn, z kar pieniężnych i grzywien, z odsetek (od udzielonych pożyczek, od nieterminowo przekazywanych należności stanowiących dochody i od środków finansowych gromadzonych na rachunkach bankowych), z dotacji z budżetów innych JST i z wpłat od samorządowych zakładów budżetowych. Ponadto w skład dochodów własnych gminy i powiatu wchodzą wpływy z opłat uiszczanych na podstawie odrębnych przepisów. W przypadku gminy charakterystycznym źródłem dochodów własnych są podatki lokalne, nieprzewidziane dla powiatu i województwa (art. 4 ust. 1, art. 5 ust. 1 i art. 6 ust. 1 ustawy o dochodach JST). Dochody osiągnięte przez JST z podziałem na poszczególne rodzaje dochodów (z wyłączeniem subwencji i dotacji) w latach 2007-2019 przedstawia wykres $1^{32}$.

27 B. Edwarczyk, op. cit., s. 177 i 192.

28 S. Owsiak, Finanse publiczne. Teoria..., s. 431.

29 P. Swianiewicz, Finanse samorzadowe. Koncepcje, realizacja, polityki lokalne, Municipium, Warszawa 2011, s. 31-33.

30 Dz.U. 2021, poz. 38, ze zm.; dalej: ustawa o dochodach JST.

31 Konstytucja Rzeczypospolitej Polskiej z dnia 2 kwietnia 1997 r. (Dz.U. nr 78, poz. 483, ze zm.).

32 Autor przyjął do badań ilościowych okres od 2007 r. do 2019 r. ze względu na zachodzące wówczas procesy i zjawiska społeczno-gospodarcze w Polsce i poza granicami państwa, dotyczące m.in. harmonizacji krajowych systemów prawnych i rozwiązań organizacyjnych z wytycznymi Unii Europejskiej, impetu gospodar- 


\section{Wykres 1. Dochody JST w Polsce z podziałem na poszczególne rodzaje dochodów w latach 2007-2019 (w mld zł)}

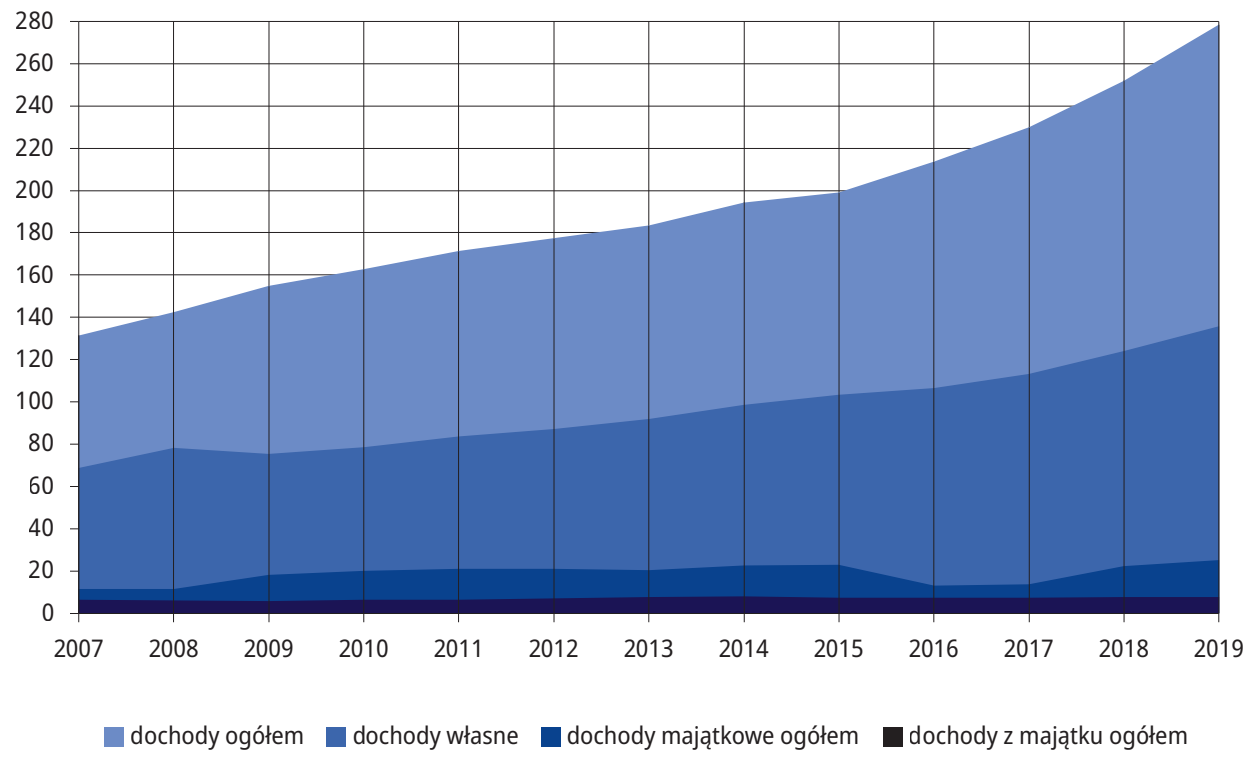

Źródło: opracowanie własne na podstawie danych Głównego Urzędu Statystycznego, Bank Danych Lokalnych, https://bdl.stat.gov.pl/BDL/start [dostęp: 20 listopada 2020 r.].

Udział dochodów własnych w dochodach ogółem JST średniorocznie kształtował się na poziomie ponad 50\% w latach 2007-2019 (w ostatnich pięciu badanych latach udział ten zmniejszył się z 51,98\% w 2015 r. do 48,75\% w 2019 r.). Wartość dochodów własnych w 2019 r. wynosiła 136 mld zł (wzrost o 97,64\% w stosunku do 2007 r.; w tym samym okresie wartość dochodów ogółem zwiększyła się o 112\%). W 2019 r. wartość dochodów majątkowych ${ }^{33}$ wynosiła ponad 25 mld zł (9,05\% udziału w wartości dochodów ogółem; 18,56\% udziału w dochodach własnych). W latach 2009-2015 udział dochodów majątkowych w dochodach ogółem wynosił ponad 10\%, najmniejszy zaś przypadał w 2016 r. (6,06\%). Do budżetów JST wpłynęło 7,5 mld zł dochodów z tytułu majątku w 2019 r. (2,69\% udziału w wartości dochodów ogółem). Udział dochodów z majątku w dochodach ogółem zmniejszył się z 4,87\% w 2007 r. do 2,69\% w 2019 r. Wartość dochodów z majątku zwiększyła się o 17,19\% (wszystkie pozostałe dochody prezentowane na wykresach 1 i 2 zwiększyły wpływy o ponad 110\% w 2019 r. w porównaniu z 2007 r.). Wykres 2 przedstawia udział wybranych rodzajów dochodów w wartości dochodów ogółem JST w latach 2007-2019.

czego wskutek wykorzystania finansowania ze środków europejskich (od 2007 r.) oraz rezultatów kryzysu gospodarczego (od 2008 r.) i wydarzeń politycznych.

33 Dochody majątkowe, w odróżnieniu od dochodów z majątku, to dochody obejmujące dotacje i środki przeznaczone na inwestycje. 


\section{Wykres 2. Udział dochodów własnych, dochodów majątkowych i dochodów z majątku w do- chodach ogółem JST w Polsce w latach 2007-2019}

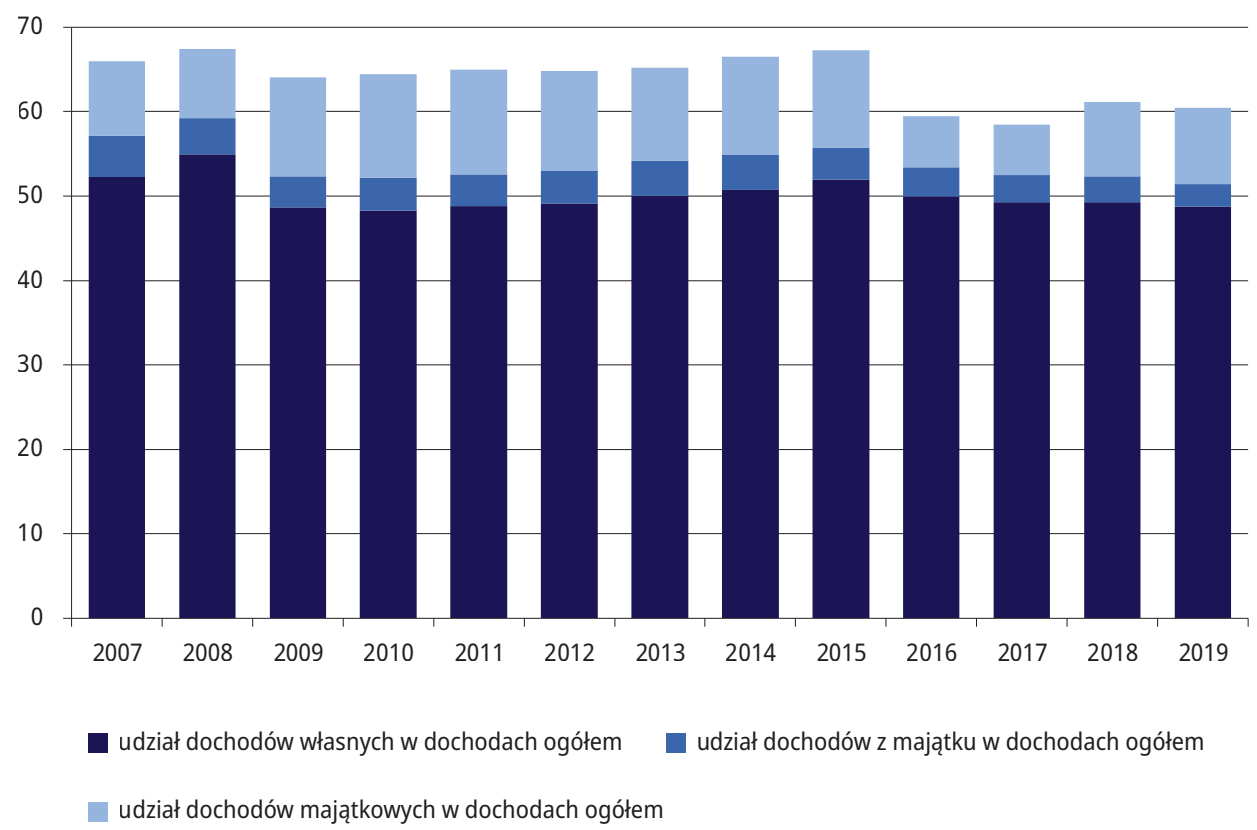

Źródło: opracowanie własne na podstawie danych Głównego Urzędu Statystycznego, op. cit.

Dochody własne powinny stanowić zasadniczą część w strukturze dochodów ogółem JST, ponieważ najlepiej odpowiadają charakterowi jednostki, która może kształtować konstrukcję dochodów własnych, swobodnie dysponować płynącymi z nich środkami, a także dopasowywać dochody własne do rzeczywistych kosztów, co pozwala na zaspokojenie potrzeb społeczności lokalnej ${ }^{34}$.

W procesie zarządzania majątkiem jednostka samorządu terytorialnego może osiągać dochody, w tym dochody z mienia, stanowiące dochody własne, do których zalicza się:

- wpływy z umów najmu, dzierżawy i innych umów o podobnym charakterze;

- odsetki od środków na rachunkach bankowych, odsetki od udzielonych pożyczek i od posiadanych papierów wartościowych;

- dywidendy z tytułu posiadanych praw majątkowych;

- dochody ze sprzedaży majątku, rzeczy i praw, niestanowiące przychodów ${ }^{35}$.

Wyżej wymienione dochody z majątku (mienia) nie stanowią zamkniętego katalogu ich źródeł, są jedynie przykładami wskazanymi przez ustawodawcę.

34 Źródła finansowania samorządu terytorialnego, red. A. Hanusz, Wolters Kluwer, Warszawa 2015, s. 29.

35 Art. 5 ust. 2 pkt 4 i 8 u.f.p. 
Spośród wszystkich JST w Polsce największe wpływy do budżetów z tytułu dochodów uzyskiwanych z majątku osiągnęły miasta (ponad 50\% w latach 2009-2019). Na wykresie 3 zaprezentowano udział dochodów z majątku uzyskanych przez poszczególne typy jednostek w dochodach z majątku ogółem wszystkich JST w latach 2007-2019.

Wykres 3. Udział dochodów z majątku uzyskanych przez poszczególne typy jednostek w dochodach z majątku ogółem wszystkich JST w latach 2007-2019

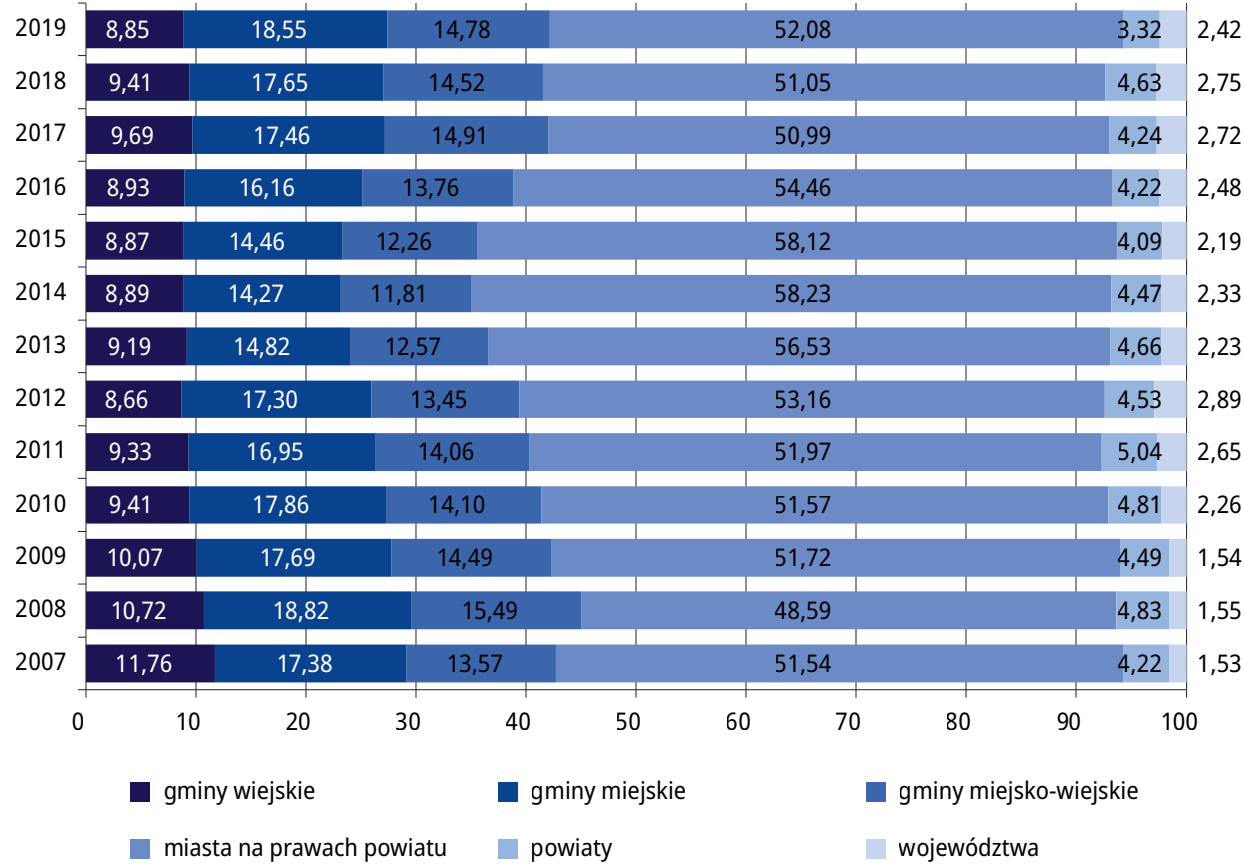

Źródło: opracowanie własne na podstawie danych Głównego Urzędu Statystycznego, op. cit.

Najznaczniejszy udział miast w strukturze JST ze względu na osiągnięte dochody z majątku wiąże się z tym, że miasta zostały wyposażone również w największy majątek, który pozwala na czerpanie wyższych korzyści z jego posiadania. Wykres 4 prezentuje kwoty dochodów z majątku poszczególnych typów JST. Należy zauważyć, że w przypadku wszystkich JST, poza gminami wiejskimi, zwiększyła się wartość osiągniętych dochodów z majątku w 2019 r. w porównaniu z 2007 r. W latach 2007-2019 na stabilnym poziomie kształtowały się wpływy z dochodów z majątku gmin (od 2016 r. wartości dochodów stopniowo rosły), powiatów i województw. W przypadku miast wpływy z majątku podnosiły się w latach 2010-2014, co było rezultatem prawie dwukrotnego wzrostu wpływów ze sprzedaży majątku w 2014 r. w stosunku do 2013 r. oraz systematycznego zwiększania się wpływów z najmu i dzierżawy majątku (85,27\% w latach 2007-2019).

Ustawodawca wyróżnił także dochody majątkowe i bieżące (i analogicznie - wydatki) w celu ustalenia źródeł gromadzenia środków publicznych w zakresach bieżącej działalności oraz za- 
Wykres 4. Dochody z majątku uzyskane przez poszczególne typy JST w Polsce w latach 20072019 (w mld zł)

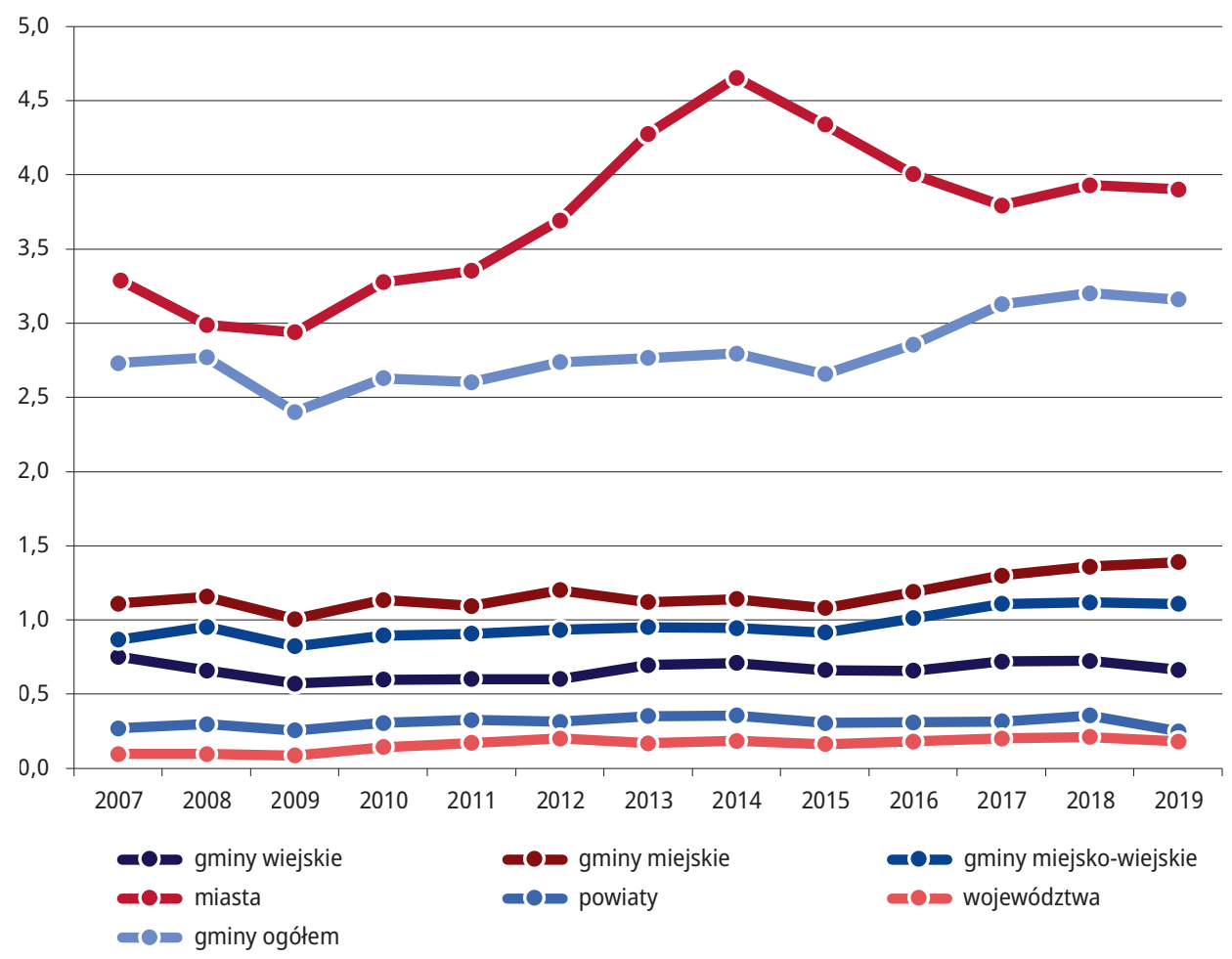

Źródło: opracowanie własne na podstawie danych Głównego Urzędu Statystycznego, op. cit.

rządzania majątkiem JST. W myśl legalnej definicji dochody bieżące to wszystkie dochody budżetowe niebędące dochodami majątkowymi (art. 235 ust. 2 u.f.p.). Do dochodów majątkowych zalicza się: dotacje i środki przeznaczone na inwestycje, dochody ze sprzedaży majątku oraz dochody z tytułu przekształcenia prawa użytkowania wieczystego w prawo własności (art. 235 ust. 3 u.f.p.). Źródłem uzyskania dochodów majątkowych jest zaangażowanie majątku podmiotu publicznego w procesy gospodarcze, w tym sprzedaż majątku (praw, rzeczy). Porównanie wartości dochodów i wydatków majątkowych osiągniętych przez gminy (zbiorczo) i miasta w latach 2007-2019 przedstawiono na wykresie 5.

Zmiana wpływów do budżetów gmin i miast w zakresie dochodów majątkowych w latach 2007-2019 odzwierciedla tendencje zmian wydatków majątkowych ponoszonych przez te jednostki. Należy zatem stwierdzić, że występuje silna zależność między dochodami a wydatkami gmin i miast w badanym okresie ${ }^{36}$. Taka sytuacja wiąże się z finansowaniem w znacznej części 
Wykres 5. Dochody i wydatki majątkowe uzyskane przez gminy i miasta w Polsce w latach 2007-2019 (w mld zł)

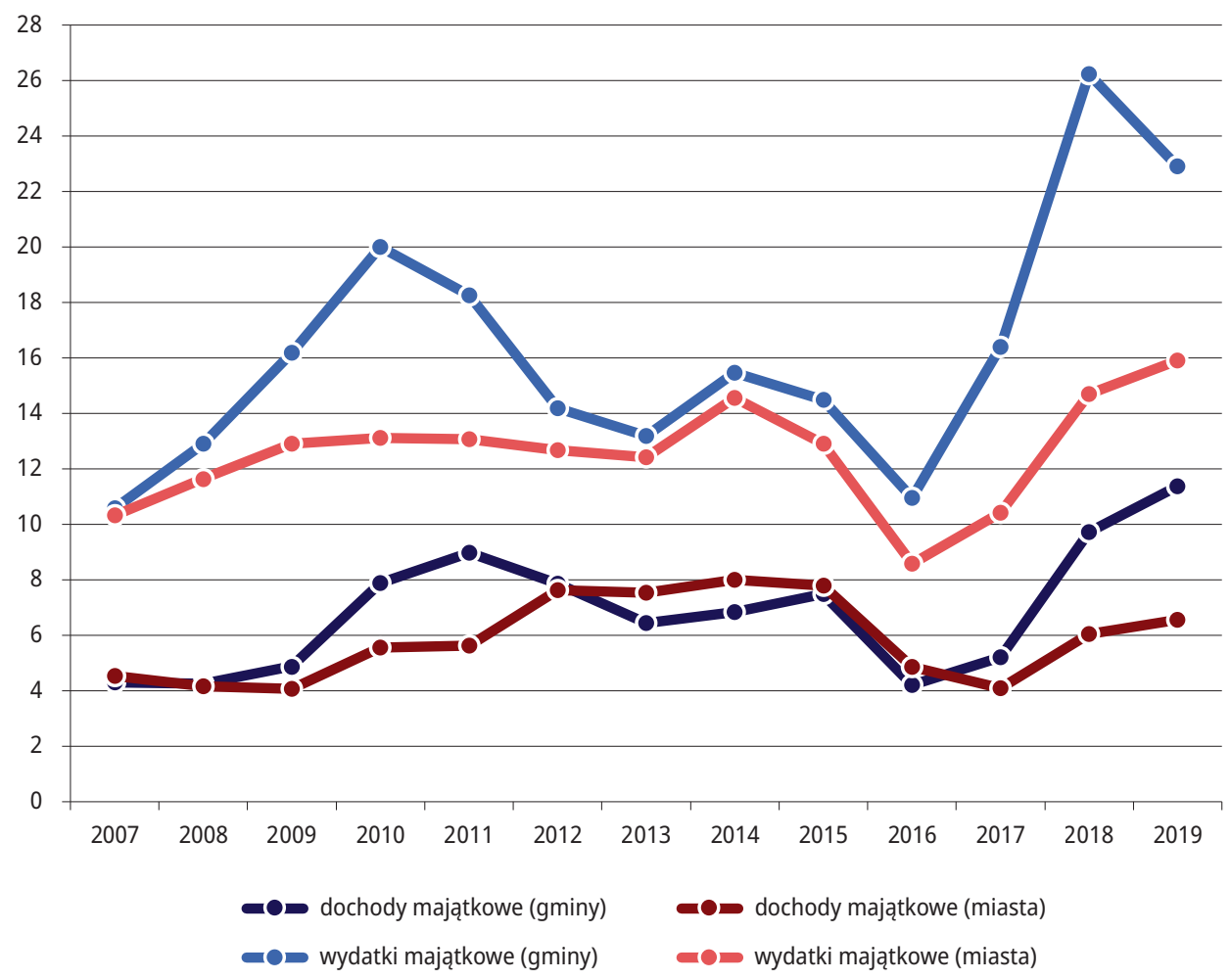

Źródło: opracowanie własne na podstawie danych Głównego Urzędu Statystycznego, op. cit.

wydatków na majątek komunalny z dotacji i środków przeznaczonych na inwestycje, w tym ze środków zewnętrznych, a także z wpływów osiąganych z tytułu dochodów ze sprzedaży majątku. Samorządy terytorialne również dochodami ze sprzedaży majątku wypełniały reguły zadłużenia, np. spłacały zaciągnięte długi ${ }^{37}$. Na zmiany wartości dochodów i wydatków majątkowych wskazują też cykle wyborcze w latach 2010, 2014 i 2018. W roku przed wyborami i w roku przeprowadzenia wyborów do organów władz samorządowych zwiększa się różnica między wartością wydatków majątkowych a wartością dochodów majątkowych, np. w 2018 r. wydatki majątkowe były wyższe od dochodów majątkowych o 170\% w przypadku gmin oraz o 144\% w przypadku miast.

37 Szerzej: B. Edwarczyk, op. cit. Por. J. Kotlińska, Sprzedaż majq̨tku samorzq̨dowego w kontekście limitu zadłużenia i zadań jednostek samorzadu terytorialnego w Polsce, [w:] Finanse wobec zmian w burzliwym otoczeniu, red. M. Dylewski, „Zeszyty Naukowe Wyższej Szkoły Bankowej w Poznaniu” t. 47, nr 2, Wydawnictwo Wyższej Szkoły Bankowej w Poznaniu, Poznań 2013, s. 49. 
W toku porównywania wartości wpływów dochodów majątkowych i dochodów z majątku (wykres 6) warto zwrócić uwagę na istotny wpływ dotacji i środków przeznaczonych na inwestycje na działalność gmin i miast w zakresie wykorzystania majątku komunalnego (intensyfikacja dochodów w latach 2010-2015 oraz od 2017 r.).

Wykres 6. Dochody majątkowe i dochody z majątku uzyskane przez gminy i miasta w Polsce w latach 2007-2019 (w mld zł)

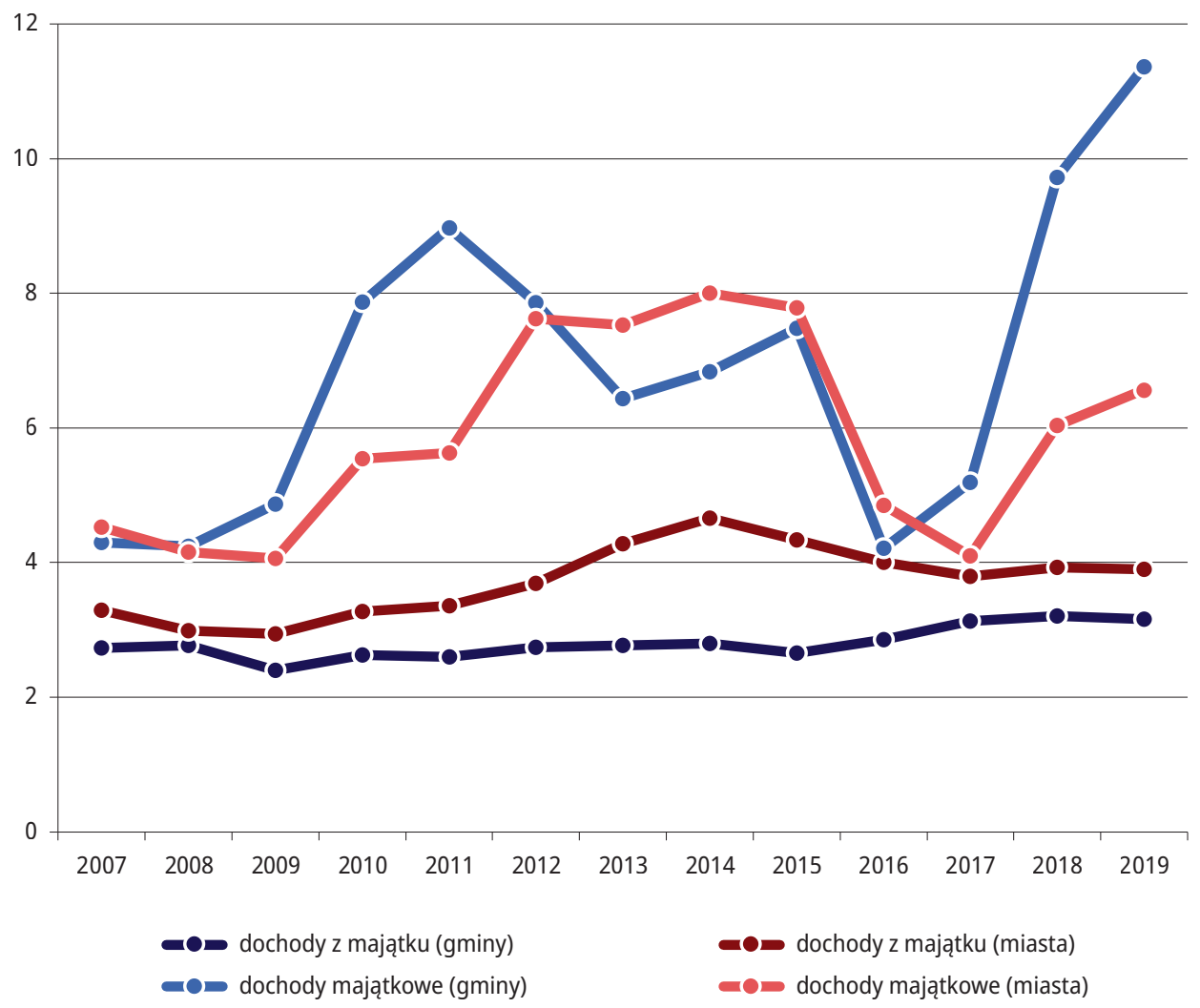

Źródło: opracowanie własne na podstawie danych Głównego Urzędu Statystycznego, op. cit.

W kwestii oceny dochodów z majątku osiągniętych przez gminy i miasta w latach 2007-2019 należy stwierdzić, że ten rodzaj dochodu był uzyskiwany przez gminy na stałym poziomie (od 2,40 mld zł w 2009 r. do 3,20 mld zł w 2018 r.). W miastach zwiększano dochody z majątku w okresie od 2010 r. (3,28 mld zł) do 2014 r. (4,66 mld zł), aby po zmniejszeniu ich w latach 2015-2016 utrzymać stabilne źródło finansowania działalności jednostek w latach 2016-2019 (od 3,79 mld zł do 4,01 mld zł). 


\section{Perspektywy zwiększenia dochodów osiąganych z majątku komunalnego}

Spośród wszystkich rodzajów dochodów organy władzy samorządu mają największy wpływ na kształtowanie dochodów z majątku komunalnego. Zarządzanie majątkiem komunalnym wiąże się jednak z zaspokajaniem potrzeb społeczeństwa, a nie z pomnażaniem zysku (wartości), w odróżnieniu od zarządzania majątkiem prywatnym. Ograniczenia w zakresie zarządzania majątkiem komunalnym przez JST wynikają zarówno z przepisów prawa, jak i z nieprodukcyjnego charakteru tego majątku ${ }^{38}$. Dochody czerpane z majątku, wykorzystywanego na podstawie umów cywilnoprawnych lub innych działań prywatnoprawnych określonych przepisami prawa cywilnego i handlowego, np. dochody z wynajmu, dzierżawy, sprzedaży, są należnościami cywilnoprawnymi JST (inny rodzaj dochodów stanowią dochody publicznoprawne przysługujące z mocy prawa, np. podatki, opłaty, subwencje i dotacje) $)^{39}$.

Według E. Wojciechowskiego naturalne jest czerpanie korzyści z majątku komunalnego ${ }^{40}$. Dochody z majątku, w ocenie S. Owsiaka, są najmniej konfliktogennym rodzajem dochodów JST, mimo że przedmiotem kontrowersji mogą być m.in. sprzedaż majątku czy też wysokość stawek czynszu za wynajem bądź dzierżawę składników majątku.

Na zmianę wartości dochodów z majątku osiągniętych przez gminy i miasta w Polsce nie ma wpływu wielkość majątku komunalnego, którym dysponują te jednostki. Cechą wspólną jest zarówno zwiększenie wartości dochodów z majątku, jak i zwiększenie wartości majątku komunalnego w latach 2007-2019, jednakże zmiany tych wartości są nieporównywalne (w badanym okresie dochody z majątku wzrosły o 17,21\%, wartość zaś majątku komunalnego podniosła się o 97,55\%). Wykres 7 prezentuje zmiany wartości dochodów z majątku i wartości majątku komunalnego gmin i miast w Polsce w latach 2008-2019. Zmiany te nie są ze sobą w żaden sposób powiązane, a więc wielkość majątku komunalnego i jej zmiana nie mają wpływu na dochody uzyskane z tego majątku przez gminy i miasta, np. wartość majątku komunalnego zwiększyła się z roku na rok o 3,88\% i 6,50\% w latach 2015 i 2016, lecz wpływy z dochodów z majątku zmniejszyły się o 6,13\% i 1,89\%. Należy jednak zauważyć, że podstawowym celem nabycia majątku komunalnego i zarządzania nim jest zaspokajanie zbiorowych potrzeb lokalnej społeczności w sferze niekomercyjnej w gospodarce. Trudno też oczekiwać, aby samorządy terytorialne nabywały majątek w celach komercyjnych (zarobkowych), jeżeli nie jest to ich zadaniem. Ponadto majątek komunalny, który już nie jest wykorzystywany w celu realizacji zadań publicznych, zazwyczaj podlega prywatyzacji, najczęściej w formie sprzedaży majątku.

Warto podkreślić, że dochody ze sprzedaży majątku komunalnego nie mogą zasilać budżetu JST w każdych warunkach. Specyfika tego źródła wpływów wynika z jednorazowego charakteru tej czynności oraz ze znaczenia majątku w wykorzystaniu do realizacji celów i zadań publicz-

38 Narastajace dysfunkcje, zasadnicze dylematy, konieczne działania. Raport o stanie samorzq̨dności terytorialnej w Polsce, Małopolska Szkoła Administracji Publicznej, Kraków 2013, s. 50.

39 A. Borodo, Samorzad terytorialny. System prawnofinansowy, wyd. 6, LexisNexis, Warszawa 2012, s. 57.

40 E. Wojciechowski, op. cit., s. 184. 
Wykres 7. Zmiana wartości dochodów z majątku uzyskanych przez gminy i miasta w Polsce w porównaniu ze zmianą wartości majątku komunalnego w latach 2008-2019 (w \%)

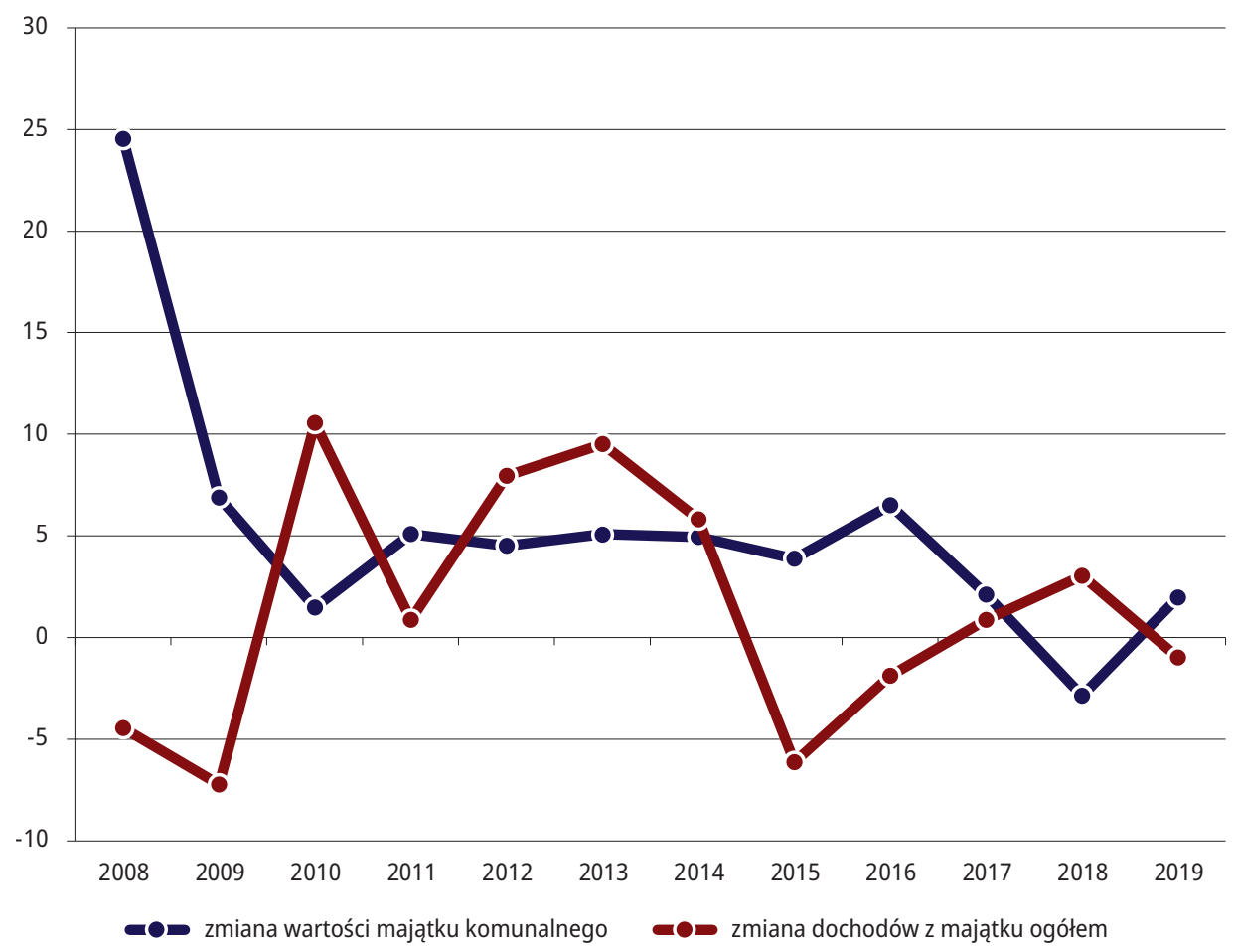

Źródło: opracowanie własne na podstawie danych Głównego Urzędu Statystycznego, op. cit.

nych ${ }^{41}$. Co więcej, za działanie patologiczne należy uznać sprzedaż majątku komunalnego w celu zwiększenia zdolności do zaciągania zobowiązań przez JST z uwzględnieniem krótkookresowych potrzeb tych jednostek. Prywatyzacja majątku komunalnego w formie sprzedaży powinna zapewnić optymalną strukturę i wielkość majątku względem wykonywanych i planowanych zadań publicznych ${ }^{42}$. W zarządzaniu majątkiem komunalnym interesy długoterminowe powinny przeważać nad interesami doraźnymi. Bez wątpienia sprzedaż majątku komunalnego pozwala na zwiększenie bieżących dochodów oraz na zminimalizowanie albo wręcz wyeliminowanie konieczności wprowadzenia dodatkowych podatków lub zaciągania zobowiązań (pożyczki, kredyty, emisja obligacji ${ }^{43}$. Na kolejnych dwóch wykresach zaprezentowano dochody z majątku, w tym dochody z jego najmu i dzierżawy oraz wpływy ze sprzedaży, uzyskane przez gminy (wykres 8) i miasta (wykres 9) w Polsce w latach 2007-2019.

41 M. Korolewska, K. Marchewka-Bartkowiak, Indywidualny wskaźnik zadłużenia samorządów terytorialnych, "Infos" 2011, nr 21(113), Biuro Analiz Sejmowych, s. 3.

42 J. Kotlińska, Sprzedaż majątku..., s. 49.

43 S. Owsiak, Finanse publiczne. Teoria..., s. 142 i 171. 


\section{Wykres 8. Dochody z majątku, w tym dochody z jego najmu i dzierżawy oraz wpływy ze sprze- daży, uzyskane przez gminy w Polsce w latach 2007-2019 (w mld zł)}

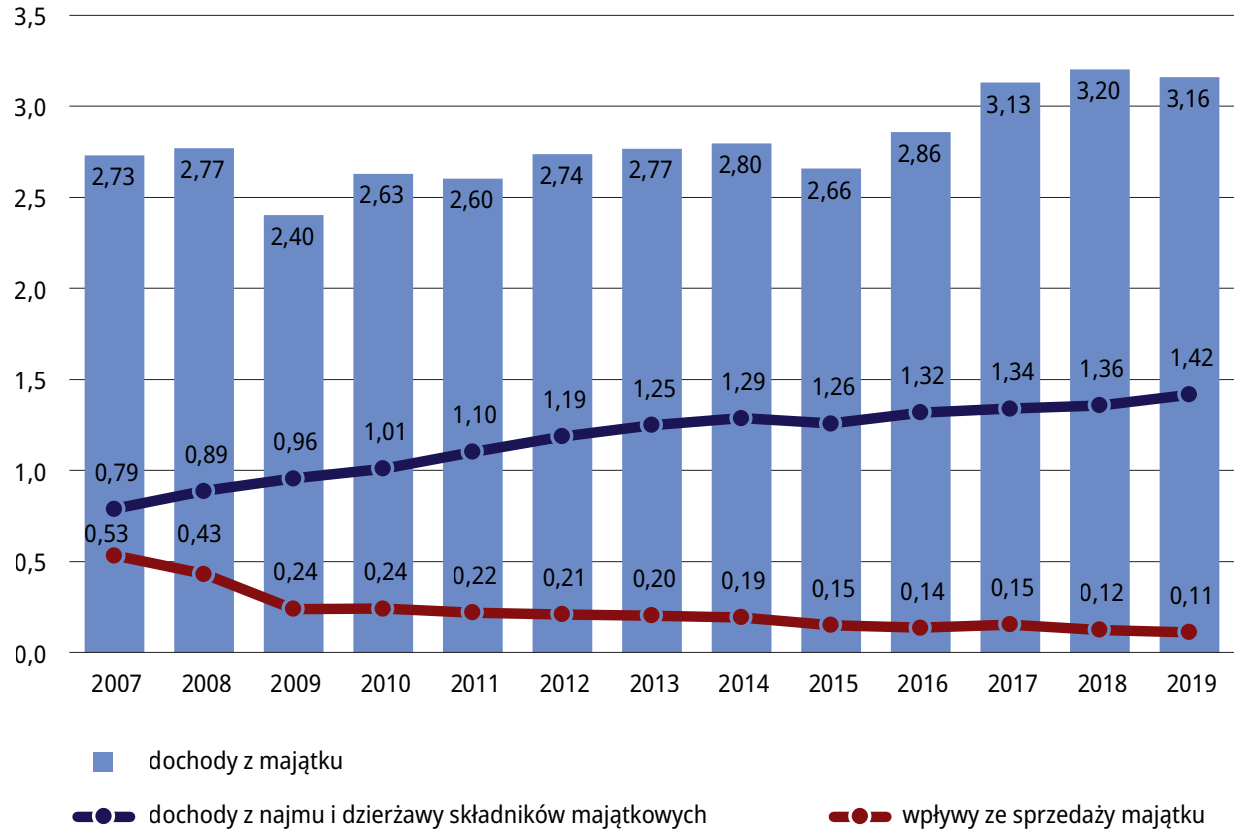

Źródło: opracowanie własne na podstawie danych Głównego Urzędu Statystycznego, op. cit.

Dochody z majątku uzyskane przez gminy i miasta zwiększyły się w latach 2007-2019. W badanym okresie dochody te podlegały wahaniom wartości ich wpływów do budżetów JST, np. dochody z majątku miast znacznie wzrosły w latach 2010-2014, aby w kolejnych latach do 2019 r. zmniejszyć i ustabilizować swoją wartość. W przypadku gmin wartość dochodów z majątku sukcesywnie rosła z roku na rok od 2009 r. (wyjątek - lata 2011 i 2015). Pozytywnym zjawiskiem jest systematyczne zwiększanie się wpływów obejmujących dochody z najmu i dzierżawy składników majątku komunalnego od 2007 r. Wartość tych dochodów osiągniętych przez gminy i miasta charakteryzowała się tendencją wzrostu i na koniec 2019 r. podwoiła się w porównaniu z 2007 r. W coraz mniejszym stopniu gminy poddają majątek prywatyzacji w formie sprzedaży (dochody ze sprzedaży majątku komunalnego zmniejszyły się pięciokrotnie w 2019 r. w stosunku do 2007 r.). Miasta również odstąpiły od istotnego zasilania budżetów wpływami ze sprzedaży majątku, jednakże wartości te zmieniają się nierównomiernie. Jedyną wspólną cechą zmiany dochodów ze sprzedaży majątku miast są znaczne odchylenia in plus w latach, w których były przeprowadzone wybory do organów władz samorządowych (2010, 2014 i 2018). Ponadto warto zauważyć, że największe wartości dochodów ze sprzedaży majątku wystąpiły w latach 2007 i 2008 w przypadku gmin oraz w latach 2007 i 2009 w odniesieniu do miast. 


\section{Wykres 9. Dochody z majątku, w tym dochody z jego najmu i dzierżawy oraz wpływy ze sprze- daży, uzyskane przez miasta w Polsce w latach 2007-2019 (w mld zł)}

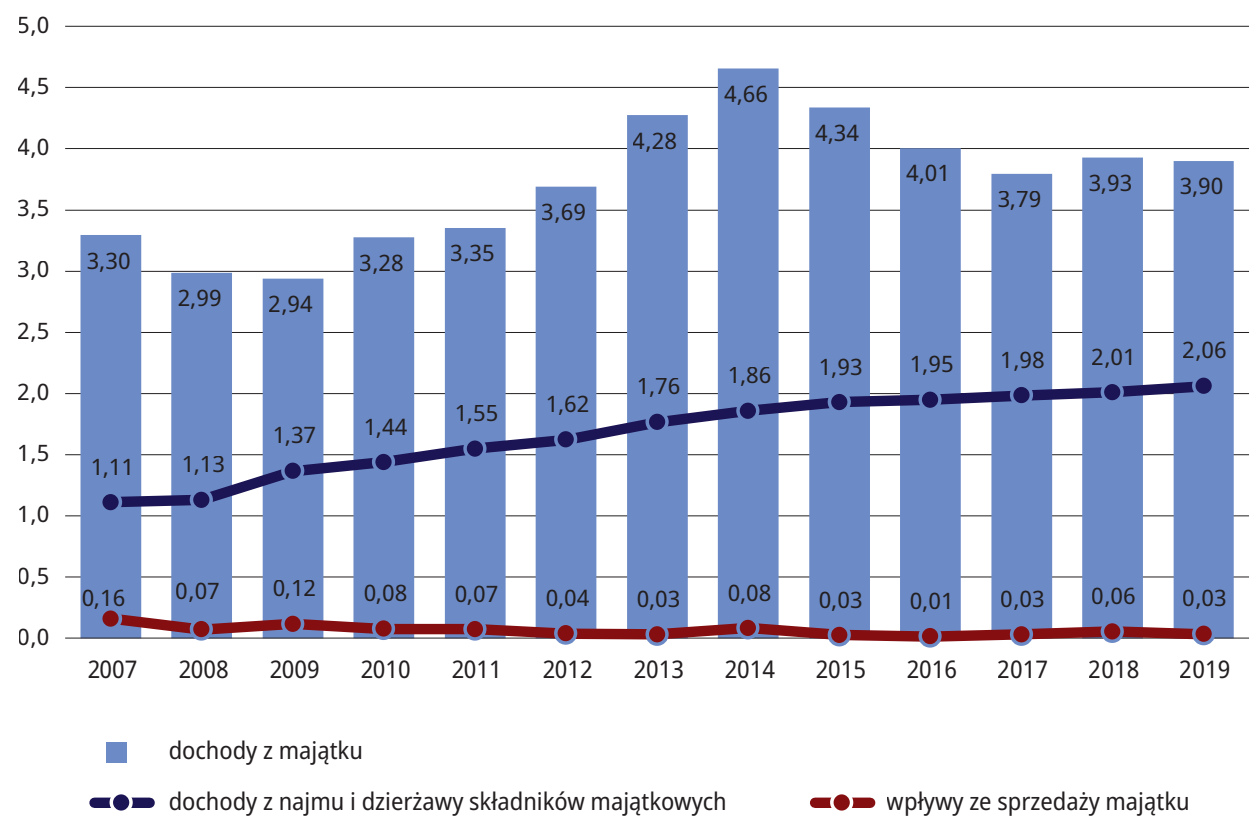

Źródło: opracowanie własne na podstawie danych Głównego Urzędu Statystycznego, op. cit.

Perspektywa zwiększenia dochodów osiąganych z najmu i dzierżawy majątku komunalnego (wykresy 8 i 9) skłania do porównania zmiany wartości wpływów z tego tytułu względem zmian wskaźnika inflacji. Wskaźnik ten wiąże się z badaniem cen towarów i usług konsumpcyjnych na rynku detalicznym oraz budżetów gospodarstw domowych (przeciętne wydatki na towary i usługi konsumpcyjne). Stawki czynszów najmu i dzierżawy majątku komunalnego, w tym ich waloryzacja, często opierają się na wskaźniku inflacji. Wykres 10 przedstawia zmiany wartości dochodów z najmu i dzierżawy składników majątku komunalnego w stosunku do zmian tego wskaźnika.

Finansowanie rozwoju i bieżącego utrzymania majątku komunalnego powinno być powiązane z możliwościami uzyskiwania dochodów z tytułu jego udostępniania społeczności. Dochody z majątku stanowią bezzwrotny instrument finansowania sfery zarządzania majątkiem komunalnym. Należy zauważyć, że majątek komunalny, który w znacznej części umożliwia zwiększanie dochodów, mimo realizacji zadań publicznych, jest zazwyczaj powierzony samorządowemu zakładowi budżetowemu lub spółce komunalnej, funkcjonujących na wolnym rynku. Czerpanie pożytku z zarządzanego majątku przez te podmioty w określonych przypadkach jest regulowane decyzją władz organu JST. Niemniej jednak wartość wpływów z dostarczania dóbr lub świadczenia usług z wykorzystaniem majątku komunalnego jest ustalana na poziomie kosztów (wydatków) pozwalających na jego utrzymanie i rozwój, np. dostarczanie wody i odprowadzanie ścieków stanowią zadania publiczne realizowane na podstawie zarządzania infrastruktu- 
Wykres 10. Zmiana wartości dochodów z najmu i dzierżawy majątku komunalnego uzyskanych przez gminy i miasta w Polsce w porównaniu ze wskaźnikiem inflacji w latach 2007-2019 (w \%)

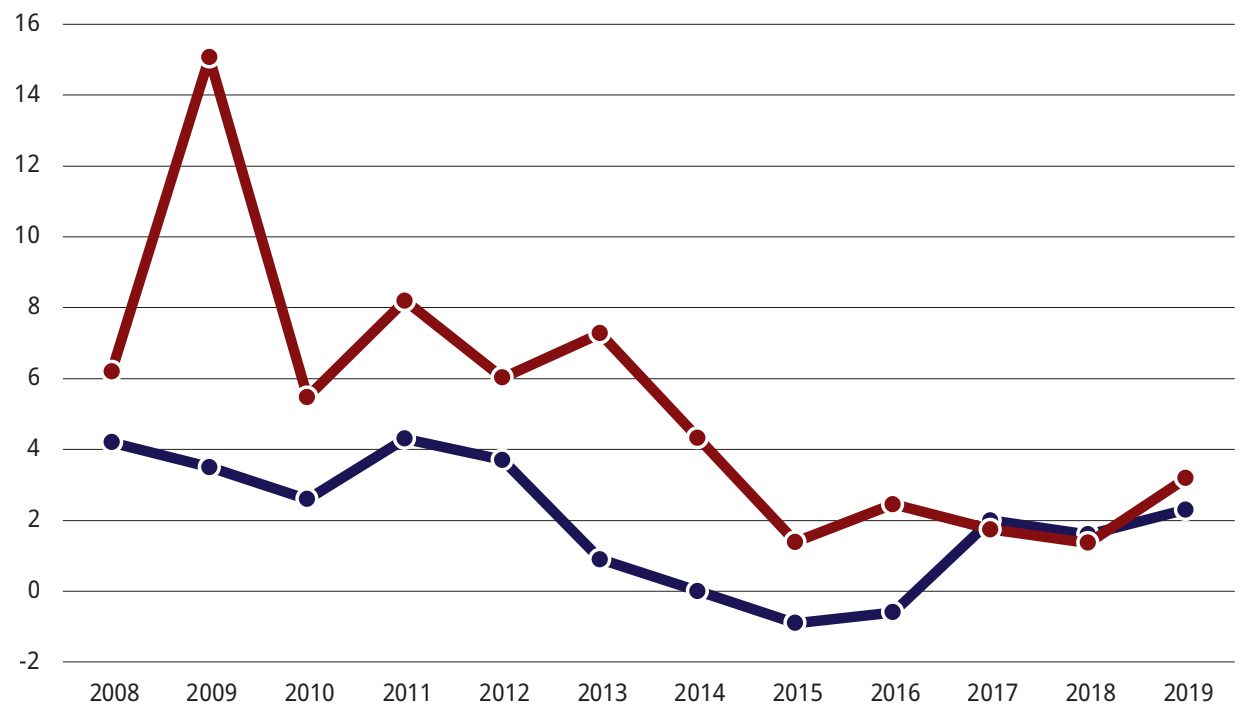

-0 wskaźnik cen towarów i usług konsumpcyjnych a zmiana dochodów z najmu i dzierżawy (gminy i miasta)

Źródło: opracowanie własne na podstawie danych Głównego Urzędu Statystycznego, op. cit.

rą wodno-kanalizacyjną. W takim wypadku od użytkowników (klientów) są pobierane opłaty zasilające budżet podmiotu zarządzającego majątkiem o charakterze publicznym. Wpływy te wynikają ze sposobu i formy zarządzania majątkiem.

Należy również zwrócić uwagę na źródła dochodów gmin i miast, których to dochodów nie kwalifikuje się jako dochodów z majątku komunalnego, jednakże ich pobór pośrednio wiąże się z jego posiadaniem. Takim przykładem dochodów są wpływy z opłat za zajęcie pasa drogowego czy za postój pojazdów w strefie płatnego parkowania, a więc dochody uzyskiwane na skutek odpłatnego udostępniania nieruchomości komunalnych.

Innym ciekawym, lecz rzadko stosowanym przez JST w Polsce źródłem dochodów z wytworzenia majątku komunalnego i dysponowania nim jest opłata adiacencka. Opłata ta jest uregulowana w ustawie o gospodarce nieruchomościami (art. 4 pkt 11). Podstawą poboru opłaty adiacenckiej jest budowa urządzeń infrastruktury technicznej z udziałem środków JST, środków pochodzących z budżetu Unii Europejskiej lub ze źródeł zagranicznych niepodlegających zwrotowi (opłata adiacencka jest również pobierana w związku ze wzrostem wartości nieruchomości na skutek podziału bądź scalenia i ponownego podziału nieruchomości). Opłata adiacencka ma charakter administracyjny, ponieważ jest nakładana na podstawie decyzji organu wykonawczego JST. Organ stanowiący JST jest zobowiązany ustalić, w formie uchwały, wysokość stawki procentowej opłaty adiacenckiej. W przypadku opłaty adiacenckiej związanej z budową 
infrastruktury komunalnej stawka procentowa nie może przekroczyć 50\% dla wzrostu wartości nieruchomości (75\% dla wzrostu wartości nieruchomości położonej na terenie Specjalnej Strefy Rewitalizacji) - art. 146 ust. 2 i 2a. Do trudności powstających przy wydawaniu decyzji określającej wysokość opłaty adiacenckiej zalicza się np. ustosunkowanie się przez organ do wzrostu wartości nieruchomości określonego w operacie sporządzonym przez rzeczoznawcę majątkowego (oraz pokrycie kosztów takiego operatu), tryb odwoławczy w postępowaniu administracyjnym (powodujący, że sprawa może toczyć się latami, organ zaś ponosi koszty, a nie osiąga żadnego dochodu z tego tytułu), 3 lata na wydanie decyzji od momentu stworzenia warunków do podłączenia do urządzeń infrastruktury technicznej lub do korzystania z tych urządzeń. Taki stan rzeczy zniechęca organy władzy JST do wdrożenia tego rodzaju opłaty, która często przysparza więcej problemów w zakresie działalności niż wpływów do budżetu.

Po przedłożeniu w 2016 r. projektu Kodeksu urbanistyczno-budowlanego przez Ministra Infrastruktury dla samorządów terytorialnych w Polsce pojawiła się perspektywa wdrożenia i poboru opłaty infrastrukturalnej, która miała zastąpić opłatę adiacencką. Proces legislacyjny związany z tym projektem ustawy został wstrzymany w 2018 r. Celem wprowadzenia opłaty infrastrukturalnej byłoby uporządkowanie stanu prawnego dla poprawienia funkcjonowania mechanizmu finansowania kosztów gmin wiążących się z uchwaleniem miejscowych planów zagospodarowania przestrzennego oraz budową infrastruktury. Mechanizm ten zakłada przeniesienie części rzeczywistych kosztów inwestycji w majątek komunalny na beneficjentów tego majątku. Dochód z poboru opłat infrastrukturalnych stanowiłby wpływy do budżetu gminy na skutek wydania decyzji administracyjnej w terminie do 2 lat od dnia wejścia w życie miejscowego planu wyznaczającego obszar ulepszenia, a więc obszar dotyczący nieruchomości, które posiadają dostęp do planowanej drogi oraz mogłyby być przyłączone do planowanej sieci wodociągowej lub kanalizacyjnej (katalog inwestycji może być rozszerzony w drodze uchwały rady gminy, np. o sieci ciepłownicze bądź elektroenergetyczne). Podstawą ustalenia i pobrania opłaty byłby szacunkowy koszt realizacji inwestycji określony w planie miejscowym. Stawka opłaty infrastrukturalnej wynosiłaby od 10 do 30\% kosztów realizacji inwestycji na obszarze innym niż obszar nowej urbanizacji oraz od 20 do 50\% na obszarze nowej urbanizacji. Opłatą infrastrukturalną byliby obciążeni właściciele oraz użytkownicy wieczyści nieruchomości znajdujących się w obszarze ulepszenia nieruchomości, zobowiązani do wniesienia opłaty w ustalonej wysokości po upływie jednego roku od dnia, w którym możliwe stało się przyłączenie nieruchomości do inwestycji. Ponadto płatność podlegałaby rozłożeniu na 5 do 10 rat rocznych, niepodlegających waloryzacji. Opłata infrastrukturalna miałaby zastąpić opłatę adiacencką ${ }^{44}$.

\section{Podsumowanie}

Majątek komunalny jest specyficznym zasobem rzeczowym, ponieważ należy do ogółu mieszkańców lokalnej społeczności i służy użyteczności publicznej oraz zaspokajaniu zbiorowych

44 Minister Infrastruktury i Budownictwa, Projekt ustawy Kodeks urbanistyczno-budowlany, nr projektu UD135, Warszawa 2016, art. 255-270, https://legislacja.rcl.gov.pl/projekt/12290463. 
potrzeb tej społeczności. Istota majątku komunalnego jako dobra wspólnego wpływa na szczególne podejście do procesu zarządzania tym majątkiem przez organy władzy JST. Majątek jest zabezpieczeniem samodzielności JST i powinien stanowić naturalne i ważne źródło pożytków zasilających finansowo wspólnotę lokalną. Niemniej jednak, w ocenie autora, zwiększenie dochodów osiąganych z majątku komunalnego nie powinno stanowić remedium na problemy JST dotyczące niewystarczających środków finansowych w ich budżetach na sfinansowanie realizacji zadań publicznych czy też niskiego wskaźnika dochodów własnych per capita. Warto zauważyć, że podstawowym źródłem zasilania budżetów JST są podatki i opłaty publicznoprawne, a więc w zakresie tego źródła należy w pierwszej kolejności poszukiwać możliwości zwiększenia wpływów z tych podatków i opłat. Bez wątpienia gospodarka finansowa JST jest sprzężona zwrotnie, w części w sposób bezpośredni, z zarządzaniem majątkiem komunalnym (np. dochody ze sprzedaży czy też z najmu bądź dzierżawy składników majątku, wydatki inwestycyjne). Z uwzględnieniem zamierzeń legislacyjnych (opłata infrastrukturalna) należy oczekiwać przenoszenia kosztów rozwoju infrastruktury komunalnej na jej bezpośrednich beneficjentów. Taka sytuacja pozwoli na zmniejszanie luki infrastrukturalnej w kraju i wypełnienie postanowień miejscowych planów zagospodarowania przestrzennego przez organy władzy JST. Ten rodzaj wpływów do budżetu JST nie przesądzałby jednak o zachowaniu trwałości dochodów z majątku; każdy nowy element infrastruktury wręcz inicjowałby dodatkowe koszty działalności wiążące się z bieżącym utrzymaniem i modernizacją infrastruktury w przyszłości.

Skala i lokalny charakter majątku komunalnego (wykresy 3 i 4) przesądzają o możliwościach pobierania z niego pożytku przez JST, jednakże zmiana wielkości majątku rok do roku nie wpływa na zwiększenie lub zmniejszenie dochodów z tego źródła (wykres 7). Samodzielność działalności JST przekłada się na zróżnicowanie wielkości dochodów z majątku komunalnego pomiędzy jednostkami. Ewentualne możliwości zwiększania dochodów z majątku mogą pogłębiać istniejącą nierównowagę fiskalną między JST. Dochody z majątku komunalnego i tak już oddziałują na tę nierównowagę, np. dochody ze sprzedaży nieruchomości zlokalizowanych na terenie uznanym za atrakcyjny inwestycyjnie są większe w porównaniu z dochodami ze sprzedaży nieruchomości znajdujących się na obszarze nieatrakcyjnym w ocenie inwestorów.

Istotą majątku komunalnego jest jego uznanie za dobro wspólnoty lokalnej, wykorzystywane do celów publicznych, z założenia niekomercyjnych. Gminy i miasta często korzystają z najprostszej formy zwiększania dochodów z majątku, czyli z jego sprzedaży, w szczególności w latach, w których były przeprowadzane wybory do organów władz JST. Wyzbycie się prawa do składników majątku komunalnego zazwyczaj jest nieodwracalne w skutkach, dlatego każda decyzja o ich prywatyzacji powinna być poprzedzona analizą zasadności ich wykorzystania do realizacji zadań publicznych nie tylko w chwili oceny przydatności, lecz także w przyszłości.

Za pozytywne zjawisko autor artykułu uważa zwiększanie wpływów do budżetu gmin i miast z tytułu najmu i dzierżawy składników majątku w latach 2007-2019 (wykresy 8 i 9). Dochody te są trwałym, długoterminowym źródłem zasilania finansowego budżetów gmin i miast. Ponadto wartości dochodów z najmu i dzierżawy majątku w analizowanym okresie zmieniały się w większym tempie niż wskaźnik inflacji (z wyjątkiem lat 2016 i 2017), co świadczy o dostosowaniu stawek czynszów z tytułu udostępniania majątku komunalnego do zmiany cen na rynku. Warto 
podkreślić też zwiększenie popularności odpłatnej formy przekazywania majątku komunalnego do korzystania przez podmioty niepubliczne bez konieczności sprzedaży składników tego majątku.

Postulowane zwiększenie dochodów z majątku komunalnego nie znajduje uzasadnienia ze względu na obowiązujący stan prawny oraz z racji podejścia organów władzy JST do zarządzania tym majątkiem jako dobrem wspólnym. Niemniej majątek komunalny posiada ogromny potencjał pozwalający na kształtowanie rozwoju społeczno-gospodarczego w obszarze lokalnym. Rozwój ten w sposób bezpośredni lub pośredni wpływa na źródła zasilania finansowego (dochodów) JST. Pożądanym kierunkiem zmian jest wdrożenie opłaty infrastrukturalnej pozwalającej na przenoszenie kosztów rozwoju infrastruktury komunalnej na jej beneficjentów. Autor proponuje, aby opłata ta nie stanowiła jednorazowego wpływu do budżetu, jak przyjmuje się w planowanych przepisach, lecz aby była stałym corocznym obciążeniem beneficjentów. Takie podejście pozwoliłoby na częściowe zrównoważenie wydatków z budżetu JST na budowę, bieżące utrzymanie i odnowienie majątku komunalnego, z którego często korzysta wiele pokoleń. Opłata miałaby charakter publicznoprawny (byłby to quasi-podatek). Do jej obliczenia można by było posłużyć się stawką określoną jako iloraz planowanych dochodów i wydatków - zarówno inwestycyjnych, jak i bieżących - wiążących się z majątkiem komunalnym w perspektywie 5 lat oraz powierzchni ogółem danej JST. Podstawę ustalenia opłaty stanowiłby iloczyn tejże stawki i powierzchni nieruchomości zadeklarowanej do podatku od nieruchomości. W tej sytuacji podmiot władający nieruchomością znajdującą się na terenie danej JST jednocześnie byłby płatnikiem opłaty. Kontrowersje wokół takiej konstrukcji opłaty przede wszystkim wynikałyby ze zróżnicowania poziomu rozwoju infrastruktury komunalnej w granicach administracyjnych danej JST i poczucia niesprawiedliwości społecznej. Warto mimo to zauważyć, że opłata ta mogłaby pozwolić na zmniejszenie luki infrastrukturalnej i na pełną realizację postanowień miejscowych planów zagospodarowania przestrzennego przez organy władzy jednostek samorządu terytorialnego.

\section{Bibliografia}

Bednarek M., Mienie. Komentarz do art. 44-55 Kodeksu cywilnego, Kantor Wydawniczy Zakamycze, Kraków 1997. Borodo A., Samorząd terytorialny. System prawnofinansowy, wyd. 6, LexisNexis, Warszawa 2012.

Czarnow S., Działalność gospodarcza jednostek samorzq̨du terytorialnego, „Samorząd Terytorialny” 2007, nr 10.

Dolnicki B., Samorząd terytorialny, wyd. 5, Wolters Kluwer, Warszawa 2012.

Dylewski M., Planowanie budżetowe w podsektorze samorządowym. Uwarunkowania, procedury, modele, Difin, Warszawa 2007.

Edwarczyk B., Rola wpływów z gospodarowania majątkiem w wypełnianiu reguł zadłużenia przez jednostki samorzqdu terytorialnego, "Studia BAS” 2016, nr 3(47) [Nowe tendencje w zarządzaniu finansami publicznymi, red. M. Korolewska, Z. Szpringer].

Ekonomika i zarządzanie miastem, red. R. Brol, Wydawnictwo Akademii Ekonomicznej im. Oskara Langego we Wrocławiu, Wrocław 2004.

Filipiak B., Finanse samorzqdowe. Nowe wyzwania bieżqce i perspektywiczne, Difin, Warszawa 2011.

Izdebski H., Samorząd terytorialny. Podstawy ustroju i działalności, wyd. 1, LexisNexis, Warszawa 2009. 
Korolewska M., Marchewka-Bartkowiak K., Indywidualny wskaźnik zadłużenia samorzq̨dów terytorialnych „ „Infos” 2011, nr 21(113), Biuro Analiz Sejmowych.

Kotlińska J., Finansowe aspekty gospodarki nieruchomościami komunalnymi w Polsce (na przykładzie dużych miast), Wydawnictwo Uniwersytetu Ekonomicznego w Poznaniu, Poznań 2009.

Kotlińska J., Sprzedaż majątku samorzq̨dowego w kontekście limitu zadłużenia i zadańjednostek samorzqdu terytorialnego w Polsce [w:] Finanse wobec zmian w burzliwym otoczeniu, red. M. Dylewski, „Zeszyty Naukowe Wyższej Szkoły Bankowej w Poznaniu" t. 47, nr 2, Wydawnictwo Wyższej Szkoły Bankowej w Poznaniu, Poznań 2013. Leoński Z., Samorzq̨ terytorialny w RP, wyd. 5, C.H. Beck, Warszawa 2006.

Minister Infrastruktury i Budownictwa, Projekt ustawy Kodeks urbanistyczno-budowlany, nr projektu UD135, Warszawa 2016, https://legislacja.rcl.gov.pl/projekt/12290463.

Narastajq̨ce dysfunkcje, zasadnicze dylematy, konieczne działania. Raport o stanie samorzqdności terytorialnej w Polsce, Małopolska Szkoła Administracji Publicznej, Kraków 2013.

Osajda K., Kodeks cywilny. Komentarz, wyd. 15, C.H. Beck, Warszawa 2015, Legalis.

Owsiak S., Finanse publiczne. Teoria i praktyka, Wydawnictwo Naukowe PWN, Warszawa 2005.

Owsiak S., Finanse publiczne. Współczesne ujęcie, Wydawnictwo Naukowe PWN, Warszawa 2017.

Regulski J., Samorząd III Rzeczypospolitej. Koncepcje i realizacja, Wydawnictwo Naukowe PWN, Warszawa 2000.

Swianiewicz P., Finanse samorzqdowe. Koncepcje, realizacja, polityki lokalne, Municipium, Warszawa 2011.

Szewczuk A., Zioło M., Zarys ekonomiki sektora publicznego, Wydawnictwo Naukowe Uniwersytetu Szczecińskiego, Szczecin 2008.

Winiarz J. et al., Kodeks cywilny z komentarzem, red. J. Winiarz, wyd. 2 zmienione, t. 1, Wydawnictwo Prawnicze, Warszawa 1989.

Wojciechowski E., Zarządzanie w samorządzie terytorialnym, wyd. 2 poprawione i rozszerzone, Difin, Warszawa 2012.

Ziółkowska W., Finanse publiczne. Teoria i zastosowanie, Wydawnictwo Wyższej Szkoły Bankowej w Poznaniu, Poznań 2010.

Źródła finansowania samorzq̨du terytorialnego, red. A. Hanusz, Wolters Kluwer, Warszawa 2015.

\section{Akty prawne}

Konstytucja Rzeczypospolitej Polskiej z dnia 2 kwietnia 1997 r. (Dz.U. nr 78, poz. 483, ze zm.).

Ustawa z dnia 23 kwietnia 1964 r. - Kodeks cywilny (Dz.U. 2020, poz. 1740, ze zm.).

Ustawa z dnia 8 marca 1990 r. o samorządzie gminnym (Dz.U. 2020, poz. 713, ze zm.).

Ustawa z dnia 28 lipca 1990 r. o zmianie ustawy - Kodeks cywilny (Dz.U. nr 55, poz. 321).

Ustawa z dnia 20 grudnia 1996 r. o gospodarce komunalnej (Dz.U. 2021, poz. 679).

Ustawa z dnia 21 sierpnia 1997 r. o gospodarce nieruchomościami (Dz.U. 2020, poz. 1990, ze zm.).

Ustawa z dnia 13 listopada 2003 r. o dochodach jednostek samorządu terytorialnego (Dz.U. 2021, poz. 38, ze zm.). Ustawa z dnia 27 sierpnia 2009 r. o finansach publicznych (Dz.U. 2021, poz. 305).

\section{Strony internetowe}

Główny Urząd Statystyczny, Bank Danych Lokalnych, https://bdl.stat.gov.pl/BDL/start. 